\title{
BASIC APPROACHES TO THE CHOICE OF MATERIAL FOR WORKING BLADES OF THE LAST STAGES OF THE LPC OF POWERFUL STEAM TURBINES
}

\author{
L.O. Slaston ${ }^{1}$, M.G. Ishchenko ${ }^{1}$, R.B. Sherfedinov ${ }^{1}$, S.V. Alyokhina ${ }^{2,3}$ \\ ${ }^{1}$ Joint-Stock Corporation "Turboatom", Kharkiv, Ukraine; \\ ${ }^{2}$ A. Podgorny Institute of Mechanical Engineering Problems of the National Academy \\ of Sciences of Ukraine, Kharkiv, Ukraine \\ E-mail: alyokhina@ipmach.kharkov.ua,tel. +38(057)294-27-94; \\ ${ }^{3}$ V.N. Karazin Kharkiv National University, Kharkiv, Ukraine
}

The paper outlines the need for a comprehensive analysis and selection of steels for the working blades of the last stages of low pressure cylinders (LPC) of high-power steam turbines. The authors reviewed the criteria and existing technical requirements for the materials of the working blades. The analysis of various grades of steels for low-pressure cylinder blades was carried out taking into account the experience of their production at JSC "Turboatom". The proposals on the use of materials of working blades with a large length of the active part are given, as well as ways for further research are outlined.

PACS: 87.19.1y

\section{INTRODUCTION}

The last stages of the low-pressure cylinder of powerful steam turbines, unlike other stages, have a number of significant features that are manifested both in nominal and variable turbine operation modes [1]. The efficiency of both the individual stages of the flow part of the turbomachine and the entire turbine plant as a whole depends on the efficiency of their work.

During operation, the working blades of the last stage of the low-pressure cylinder (LPC) experience heavy loads of static, dynamic and cyclic nature. Due to the design features - a large twist angle and variable cross section - significant tensile, bending, and torsional stresses arise in the blades. The perturbing forces acting on the blade during rotation of the turbine rotor cause tangential vibration in the disk plane, which is complicated by axial and torsional vibrations.

The blades work in an aggressive environment of wet steam containing about 154 impurities and are subject to drop-impact erosion [2]. A great influence on the state of the blade system and other structural elements of the turbine is also exerted by the temperature regime $[3,4]$.Thus, the working temperature of the blades in stationary mode corresponds to $40{ }^{\circ} \mathrm{C}$, at idle it is possible to increase the temperature to $300{ }^{\circ} \mathrm{C}$, which requires a particularly high-quality selection of materials from which they will be manufactured.

Tighter operating conditions are also caused by the following factors: decompression of the load schedule; the need for increased maneuverability; deterioration in vacuum; demand for an increase in the overhaul period and service life. All of the above factors must be taken into account as carefully as possible even at the stages of design and production of a blade system. For these reasons, it is necessary to make a selection of materials based on an analysis of their properties and taking into account the conditions in which the blades will be used. Therefore, the aim of this work is to highlight the main criteria and approaches to the choice of steel blades of the last stages of the low pressure cylinder of powerful steam turbines.

\section{CURRENT STATE OF THE ART IN MATERIAL SELECTION FOR ROTOR BLADES}

A rather large number of scientific research papers are devoted to the selection of materials for working blades of steam turbine cylinders [5-11]. However, they all have a fairly narrow specificity, often focused on the study of very specific materials available to the manufacturer, or, for example, cover only some aspects related to operation, and do not take into account the features of production processes.

So, in works $[5,6]$, the analysis of thermal strength processes occurring in the blade system of gas turbines was carried out. The analysis was carried out using widely used mathematical modeling codes by simulating processes in an object made from a narrow list of materials. Despite the fact that such an engineering approach is effective in a number of cases, it cannot be extended to a wide class of tasks related to the design of LPC blades of powerful steam turbines.

Another approach that is often found in the literature is the development of methods for improving the quality of materials for a blade system based on known operating results. For example, in works $[7,8]$ it was proposed to use a number of steels for repairing damaged steam turbine blades. Although such research works have a rather large applied value, they still do not solve the problem of determining the criteria for choosing the material at the stage of design of the blade system.

It is also worth noting the works [9-11], which also highlighted the choice of steels for turbomachine blades using various mathematical methods. The results of the presented studies are focused on gas turbine blades, the operating conditions of which differ significantly from those in steam turbines. In all of the above works, there is no consolidated criteria list that must be considered when choosing steels for LPC blades. In the same case, when some criteria are nevertheless indicated, their choice was made without taking into account the experience in the production of a blade system and operation of turbines in various operating modes. 


\section{BASIC CRITERIA FOR MATERIAL SELECTION}

Over the past few years, JSC "Turboatom" has been actively working on the design and arrangement of the production of working blades with a large length of the active part. Such blades, in particular, include blades with a length of $1100,1200,1650,1750 \mathrm{~mm}$, which are used in the last stages of the low-pressure cylinder with increased throughput of high-speed turbines.

The assessment of the possibility of using materials for the manufacture of blades was carried out on the basis of specified technical requirements for the material of the blades. So, the material of the blades of the last stage of the low pressure cylinder must satisfy the following basic requirements:

1. In the chemical composition of the material of the blades, the content of harmful impurities and gases should be limited. The metal of the blades must have high chemical and structural homogeneity. The limits of the content of chemical elements should be narrowed to the minimum acceptable restrictions associated with the melting process.

2. The metal should be dense, permissible defects during ultrasound diagnostics should not exceed $2 \mathrm{~mm}$.

3 . The mechanical properties under tension and impact bending at $20^{\circ} \mathrm{C}$ should be within the limits indicated in the Table 1.

4. Permissible decrease in strength characteristics with temperature increase up to $300{ }^{\circ} \mathrm{C}$ is no more than $10 \%$. Differences in mechanical properties over the cross section and length of the blades should not exceed $10 \%$, which should be ensured by high chemical and structural homogeneity.

5. The fracture appearance transition temperature determined by the criterion of a $50 \%$ viscous component in the fracture of shock specimens with a sharp notch is not higher than $0{ }^{\circ} \mathrm{C}$.

6. Characteristic of static crack resistance $\mathrm{K}_{1 \mathrm{C}}$ at $20{ }^{\circ} \mathrm{Cis}$ not less than $150 \mathrm{MPa} \sqrt{\mathrm{m}}$.

7. The level of characteristics of resistance to fatigue failure should be within the limits indicated in the Table 2 based on $10^{8}$ cycles.

8. High resistance to corrosion fatigue, general and local corrosion. The loss of blade thickness should not exceed $0.03 \mathrm{~mm}$ per year.

9. Resistance to droplet impact erosion is not less than $1 \ldots 2$ points of resistance according to the Table 3 PTM 108.020.15-86. "Metals for turbines and heat exchange equipment of nuclear power plants. Recommendations on the choice of metals" [12]. The average wearing depth at the input edge should not exceed $1.5 \mathrm{~mm}$ for a period of 40 thousand hours. When using materials having an erosion resistance of less than 2 points, the technological properties of the material should provide the possibility of using anti-erosion hardening of the edges of the blades.

10. The damping properties of the material of the blades should be at the level of steel $12 \mathrm{H} 13$, which has a high ability to oscillation suppression.

The material for the blades should have the following technological properties:
1. The absence of pronounced segregation in the process of solidification in ingots.

2. Low tendency to heterogeneity during hot plastic deformation.

3. Low tendency to hairline formation during rolling and forging blanks.

4. Satisfactory deformability, which provides forging by stamping the blade of the desired profile and size.

5. Satisfactory machinability during cold machining.

6. Satisfactory weld ability during welding and satisfactory process ability during soldering, lack of tendency to crack formation in the heat affected zone, high resistance to local destructions in the welding and soldering zone, lack of softening in these zones.

7. To improve technological properties, it is recommended to use additives of rare-earth elements, as well as progressive methods of smelting, providing a decrease in the content of gases and non-metallic inclusions - smelting in vacuum - slag and vacuum-arc remelting.

Table 1

Mechanical properties at $20^{\circ} \mathrm{C}$

\begin{tabular}{|c|c|c|c|c|c|c|c|}
\hline $\begin{array}{l}\sigma_{0.2}, \\
\mathrm{MPa}\end{array}$ & $\begin{array}{l}\sigma_{\mathrm{B}}, \\
\mathrm{MPa}\end{array}$ & $\delta, \%$ & $\psi, \%$ & $\sigma_{0.2} / \sigma_{\mathrm{B}}$ & $\underline{I}$ & $\vartheta^{2} \underset{\infty}{\infty}$ & $\vec{v}$ \\
\hline $\begin{array}{c}730- \\
850\end{array}$ & $\geq 900$ & $\geq 13$ & $\geq 45$ & $\leq 0.8$ & $\begin{array}{l}\frac{m}{m} \\
\text { gे } \\
\text { dे }\end{array}$ & $\geq 50$ & \\
\hline
\end{tabular}

Table 2

Characteristics of resistance to fatigue failure

\begin{tabular}{|c|c|c|}
\hline$\sigma_{-1}, \mathrm{MPa}$ & $\sigma_{-1 \mathrm{H}}, \mathrm{MP0a}$ & $\mathrm{K}_{\sigma}=\sigma_{-1} / \sigma_{-1 \mathrm{H}}$ \\
\hline \multicolumn{3}{|c|}{ no less } \\
\hline $0.5 \sigma_{\mathrm{B}}$ & $0.3 \sigma_{\mathrm{B}}$ & 1.5 \\
\hline
\end{tabular}

As a result of fulfilling the requirements for the material of the blades, their service life should be at least 120 thousand hours, and the overhaul period of at least 40 thousand hours.

\section{RESULTS DISCUSSION}

As mentioned above, the requirements for the working blades of the last stages of the low pressure cylinder are extremely stringent for the currently used blade materials, and the choice of materials and optimization of their service properties are problematic. For this, several classes of steels were analyzed.

Stainless steel with $12 \%$ chromium martensitic class found the most widespread use as a blade material in turbine engineering. An increase in the strength characteristics of the blades can be achieved through the use of maraging steels or austenitic-martensitic steels [12-17].

\section{MARTENSITIC STEELS}

Steel 15H11MF-Sh has the optimal combination of strength, ductility and impact toughness characteristics for strength category KP 70. Steel has satisfactory damping properties. Steel is technologically advanced in the production of blades. An increase in strength and resistance to fatigue failure of steel is theoretically possible if isothermal hardening and low-temperature tempering are used. However, the introduction of such a 
regime requires the creation of special equipment for large blades.

Steel has insufficient corrosion and erosion resistance. The hardening of the HDTV does not provide the longevity of the blades required by modern requirements.

Steel has been successfully used in the practice of turbine engineering; there is extensive experience in operating blades of this steel with an active part length of $1030 \mathrm{~mm}$.

Alloying steel $13 \mathrm{H} 11 \mathrm{H} 2 \mathrm{~B} 2 \mathrm{MFSh}$ allows you to get the strength category KP 75 in combination with crack resistance, slightly greater than that of steel $15 \mathrm{H} 11 \mathrm{MF}$ Sh, however, steel 13H11H2B2MFSh also requires erosion protection of the input edges. Steel $13 \mathrm{H} 11 \mathrm{H} 2 \mathrm{~B} 2 \mathrm{MFSh}$ is less technologically advanced in the process of stamping and heat treatment in comparison with steel 15H11MF-Sh.

JSC "Turboatom" has accumulated positive experience in the operation of steel obtained for blades with an active part length more of $900 \mathrm{~mm}$.

\section{MARAGING STEELS}

Strength, ductility and toughness of steel EP-678VD are stable up to a temperature of $250{ }^{\circ} \mathrm{C}$. Steel belongs to the "completely resistant" materials for resistance to oxidation in a free steam, does not show a tendency to corrosion cracking. In terms of corrosion fatigue, steel is superior to steel of type $15 \mathrm{H} 11 \mathrm{MF}-\mathrm{Sh}$, but inferior to steel EP-410USHand EP-310 with a chromium content of $14 \ldots 15 \%$. The damping constant is two or more times lower than that of steel $12 \mathrm{H} 13$, but of the same order as steel EP-410US hand higher than that of titanium alloys. Steel is technologically advanced during heat treatment: it has good hardenability, it can be cooled at any speed without cracking. The use of steel for the blades is limited due to the difficulty of hardening the edges of the blades and insufficient corrosion fatigue strength.

Steel EP-410USh has high strength combined with good ductility and impact toughness due to the formation of low-carbon martensite. Due to the presence of a small amount of residual austenite, steel is not prone to fracture failure even at a temperature of $-100{ }^{\circ} \mathrm{C}$. The operating temperature of steel should be limited to 250 ${ }^{\circ} \mathrm{C}$, it is possible to increase the temperature to $350{ }^{\circ} \mathrm{C}$ for no more than 10000 hours. Steel has a high corrosion resistance due to the presence of chromium and copper, in wet steam with free access of air it is classified as "completely resistant". In terms of erosion resistance it exceeds steel $15 \mathrm{H} 11 \mathrm{MF}-\mathrm{Sh}$ to a considerable degree, and in damping properties it is significantly inferior to this steel [13, 17]. Steel is well forged, stamped, rolled, and welded. However, during heat treatment it has insufficient manufacturability due to the high sensitivity to the cooling rate during hardening and tempering. Steel is prone to temper brittleness due to the release of finely dispersed strengthening particles of the $\sum$-phase with copper.

Mechanical processing of steel due to high strength is difficult. Permissible cutting speeds are halved compared to steel $15 \mathrm{H} 11 \mathrm{MF}-\mathrm{Sh}$ due to the presence of a crust that must be removed by etching.
Lack of manufacturability during heat treatment makes it difficult to use. A special technology of smelting and heat treatment is needed, which provides a given amount of austenite.

\section{AUSTENITIC-MARTENSITIC STEELS}

Steel of austenitic-martensitic class belong to medium carbon. A feature of steels is a combination of high strength with ductility and impact toughness; steels have high corrosion and mechanical strength and erosion resistance. Austenitic-martensitic steels are more corrosion-resistant than martensitic steels. The advantage of these steels over 15H11MF-Shand 13H11H2B2MFSh is that they can be alloyed with a large amount of chromium to increase corrosion resistance, whereas in steels of the $15 \mathrm{H} 11 \mathrm{MF}-\mathrm{Sh}$ type, the increase in chromium content is limited by the formation of $\delta$-ferrite, which reduces the ductility and toughness of the steel, and also worsens its ability to hot deformation. Austeniticmartensitic steels compared to martensitic have good cold deformation ability and good weld ability even with a relatively high content of carbon and nitrogen.

These steels, like classic austenitic steels, can be subjected to stamping, deep drawing and other complex technological operations of shaping in the cold state.

Of the grades of steel of the austenitic-martensitic class, EP-310SH steel is of most interest due to the fact that steel is used for blades in the aircraft industry. This steel is not sensitive to temper brittleness and does not show a tendency to fracture failure in the temperature range from -60 to $200^{\circ} \mathrm{C}$. Compared with steel $15 \mathrm{X} 11 \mathrm{MFSh}$, it has a higher endurance limit, is less sensitive to stress concentration during cyclic loading, and is more corrosion resistant. The erosion resistance of EP-310SHsteel is higher than that of steel 15H11MFSh and is close to steel hardened by HDTV. EP-310Sh steel was used to make pilot blades of the third stage of the LPC. According to the recommendations of CNIITMASH, it is possible to use this steel for blades of the fifth stage of the LPC.

\section{CONCLUSION}

Taking into account the analysis of the operating conditions of the working blades of the last stages of the LPC, the possibility of using martensitic, martensitic-aging and austenitic-martensitic steels $15 \mathrm{H} 11 \mathrm{MF}$, 13H11H2B2MFSh, EP-410USH, EP-678BD, EP-310SH as the main material for their production is considered. These materials can be arranged in the following series in increasing fatigue strength, resistance to brittle and erosion-corrosion destruction: 15H11MF, 13H11H2B2MFSh, EP-410USHEP-678VD, EP-310SH. At JSC "Turboatom", positive operating experience has been accumulated for $15 \mathrm{H} 11 \mathrm{MF}, 13 \mathrm{H} 11 \mathrm{H} 2 \mathrm{~B} 2 \mathrm{MFSh}$ steels, which makes it possible to distinguish them as the main ones when used for the production of blades. However, when using $13 \mathrm{H} 11 \mathrm{H} 2 \mathrm{~B} 2 \mathrm{MFSh}$ steel, it is also necessary to solve the problem of anti-erosion protection of the blade inlet edges. From the point of view of manufacturability, martensitic steels are inferior to austenitic-martensitic steels, which must be taken into account when manufacturing blades with a large length of the active part. 


\section{REFERENCES}

1. V.L. Shvetsov, L.A. Zarubin, Z.D. Boguslavskaya, T.I. Shvedova. The results of experimental studies of the model compartment of the low-pressure cylinder of the K-320-240 turbine of OJSC "Turboatom" // Engineering problems. 2009, v. 12, N 1, p. $16-25$.

2. V.A. Belous, G.I. Ishchenko, M.G. Ishchenko, V.I. Kovalenko, L.I. Martynenko, V.G. MarininResearch of erosion of superficial layer of shoulder-blade steel of $15 \mathrm{Kh} 11 \mathrm{MF}$ at microimpact influence // Problems of Atomic Science and Technology. 2018, N 2(114), p. 119-124.

3. S. Alyokhina, A. Kostikov, M. Satayev, A. Saipov. Numerical Calculation Of Conjugate Heat Transfer In End Seals Of Steam Turbines // Computational Thermal Sciences. 2016, 8(5), p. 483-488; DOI: 10.1615/Comput Thermal Scien.2016017179.

4. S. Alyokhina. The operating processes in exhaust hood of steam turbine high pressure cylinder // Proceedings of the International Symposium on Turbulence, Heat and Mass Transfer. 2012, September, p. 656-659; DOI:10.1615/ICHMT.

5. P. Kezia, S. Blnk. Analysis of gas turbine blade assembly to evaluate the performance of various nickel based alloys // Int. J. Mech. Eng. Technol. 2017, v. 8(5), p. 665-673.

6. V. Theju, P.S. Uday, P. Gopinath Reddy, C.J. Manjunath. Design and analysis of gas turbine blade // International Journal of Innovative Research in Science, Engineering and Technology. 2014, v. 3(6), p. 13533-13539.

7. A.K. Bhaduri, T.P.S. Gill, S.K. Albert, K. Shanmugam, D.R. Iyer. Repair welding of cracked steam turbine blades using austenitic and martensitic stainless-steel consumables // Nucl. Eng. Des. 2001, v. 206(2-3), p. 249-259.
8. X. Zhang, W. Li, F. Liou. Damage detection and reconstruction algorithm in repairing compressor blade by direct metal deposition // Int. J. Adv. Manuf. Technol. 2018, v. 95(5-8), p. 2393-2404.

9. A. Hafezalkotob, A. Hafezalkotob. Risk-based material selection process supported on information theory: A case study on industrial gas turbine // Appl. Soft Comput. J. 2017, v. 52, p. 1116-1129.

10. A. Shanian, A.S. Milani, C. Carson, R.C. Abeyaratne. A new application of ELECTRE III and revised Simos' procedure for group material selection under weighting uncertainty // Knowl. Based Syst. 2008, v. 21(7), p. 709-720.

11. A. Hafezalkotob, A. Hafezalkotob. Extended MULTIMOORA method based on Shannon entropy weight for materials selection // J. Ind. Eng. Int. 2015, v. 12(1), p. 49-53.

12. PTM108.020.15-86. Metals for turbines and heat exchange equipment of nuclear power plants. Recommendations for the selection of metals. General technical requirements. $108 \mathrm{p}$.

13. High strength stainless steels for parts of power plants. Guidelines // L.: CKTI. 1979, issue 41, 58 p.

14. Steel and alloys grade guide. M.: "Engineering", 2001, $672 \mathrm{p}$.

15. S.B. Maslenkov. Heat resistant steels and alloys. Directory. M.: "Metallurgy", 1983, 191 p.

16. A.M. Lyapunov. Development of a technology for heat treatment of blanks for LPC blades of steam turbines made of high-strength steel 13X15H4AM3 in order to increase their durability. The dissertation in support of candidature for a technical degree. M., 1990, $197 \mathrm{p}$.

17. Ye.Ye. Levin, Ye.N. Masaleva, D.M. Bavelsky. Maraging stainless steel ЭП410УШ for compressor blades designed to operate in freezing temperatures // Proceedings of CKTI. 1973, issue 116, p. 68-76.

Article received 03.12.2019

\section{ОСНОВНЫЕ ПОДХОДЫ К ВЫБОРУ МАТЕРИАЛА ДЛЯ РАБОЧИХ ЛОПАТОК ПОСЛЕДНИХ СТУПЕНЕЙ ЦНД МОЩНЫХ ПАРОВЫХ ТУРБИН}

\section{Л.А. Сластён, М.Г. Ищеенко, Р.Б. Шерфединов, С.В. Алёхина}

Обозначена необходимость проведения комплексного анализа и выбора сталей для рабочих лопаток последних ступеней цилиндров низкого давления (ЦНД) паровых турбин большой мощности. Авторами рассмотрены критерии и существующие технические требования к материалам рабочих лопаток. Проведен анализ различных марок сталей для лопаток ЦНД с учетом опыта их производства в АО «Турбоатом». Даны предложения по использованию материалов рабочих лопаток с большой длиной активной части, а также намечены пути проведения дальнейших исследований.

\section{ОСНОВНІ ПІДХОДИ ДО ВИБОРУ МАТЕРИАЛУ ДЛЯ РОБОЧИХ ЛОПАТОК ОСТАННІХ СТУПЕНІВ ЦНТ ПОТУЖНИХ ПАРОВИХ ТУРБІН}

\section{Л.О. Сластьон, М.Г. Іщценко, Р.Б. Шерфедінов, С.В. Альохіна}

Вказано на необхідність проведення комплексного аналізу і вибору сталей для робочих лопаток останніх ступенів циліндрів низького тиску (ЦНТ) парових турбін великої потужності. Авторами розглянуті критерії та існуючі технічні вимоги до матеріалів робочих лопаток. Проведено аналіз різних марок сталей для лопаток ЦНТ з урахуванням досвіду їх виробництва в АТ «Турбоатом». Надано пропозиції щодо використання матеріалів робочих лопаток з великою довжиною активної частини, а також намічені шляхи проведення подальших досліджень. 